license

\title{
The State Response toward the Existence of HTI: An Analysis from Social Movement Study Approach
}

\author{
Hasbi Aswar ${ }^{1}$, Danial Bin Mohd Yusof ${ }^{2}$, Rohana Binti Abdul Hamid ${ }^{3}$ \\ hasbiaswar@uii.ac.id, danialmy@iium.edu.my, rohanahamid@iium.edu.my \\ ${ }^{13}$ Department of Political Science, Kulliyah of Islamic Revealed Knowledge and Human Sciences, International \\ Islamic University of Malaysia; Universitas Islam Indonesia \\ ${ }^{2}$ International Institute of Islamic Thought and Civilization (ISTAC), International Islamic University of Malay sia \\ DOI http://dx.doi.org/10.22219/sospol.v6i2.12908
}

\begin{abstract}
As a global Islamic political group, Hizb ut-Tahrir (HT) has experienced many kinds of state coercive responses due its ideas that considered radical and threatening the existing modern political systems. In many places, this group has been rejected and criminalized by regimes either in Muslim majority states or in the Western states. The same experience has also been faced by HT in Indonesia that went through the change of state policy from accommodating to repressive approach. This study will focus to elaborate the response of the Indonesian government toward HTI from the lens of social movement studies by using state repression concept. This article uses the explanatory method analysis and collects data mainly from literature. This article argues that the state has used several methods to repress HT such as issuing an extraordinary law in dissolving HTI; intimidating HTI`s supporters and activists and stigmatizing or discrediting HTI image. As the result, in 2017 Indonesian government dissolved HTI, then HTI became one of forbidden organizations in Indonesia.
\end{abstract}

\section{Abstrak}

Sebagai sebuah kelompok politik Islam global, Hizbut Tahrir (HT) telah mengalami berbagai macam respon negara yang bersifat memaksa karena pemikirannya yang dianggap radikal dan mengancam sistem politik modern yang ada. Di banyak tempat, kelompok ini telah ditolak dan dikriminalisasi oleh rezim baik di negara bagian mayoritas Muslim atau di negara bagian Barat. Pengalaman yang sama juga dialami oleh HT di Indonesia yang mengalami perubahan kebijakan negara dari pendekatan akomodatif menjadi represif. Kajian ini akan fokus untuk mengelaborasi respon pemerintah Indonesia terhadap HTI dari kacamata kajian gerakan sosial dengan menggunakan konsep represi negara. Artikel ini menggunakan analisis metode penjelasan dan mengumpulkan data terutama dari literatur. Pasal ini berpendapat bahwa negara telah menggunakan beberapa cara untuk menekan HT seperti mengeluarkan undang-undang luar biasa dalam pembubaran HTI; mengintimidasi pendukung dan aktivis HTI dan menstigmatisasi atau mendiskreditkan citra HTI. Alhasil, pada tahun 2017 pemerintah Indonesia membubarkan HTI, kemudian HTI menjadi salah satu organisasi terlarang di Indonesia.

\author{
Keywords \\ Hizb ut-Tabrir \\ Indonesia, Indonesian \\ Government, \\ Radicalization Threat, \\ State Repression, Social \\ Movement
}

\section{Article History}

Received July 16, 2020

Revised August 13, 2020

Accepted August 25, 2020

Published October 16, 2020

\section{Corresponding}

Author

Hasbi Aswar.

Kaliurang St No.Km.

14,5, Krawitan,

Umbulmartani,

Ngemplak, Sleman

Regency, Special

Region of Yogyakarta.

55584

\section{Introduction}

In a social movement phenomenon, when a movement is perceived to bring a threat to the existing social or political condition, other movements will arise to respond or counter it or there will be a response from the state either to repress or to facilitate the movement. If the movement is welcomed by the state, then there will be no conflict between the state and that movement. Otherwise, if the state represses the movement, then conflict between the two actors will happen, whereby there will be a contest to be the winner in the political competition. Social movements will fight to change and state will come to counter and to contain the influence of 
the movement. The state will make any effort to end the movement, on the other hand, the movement will find out other ways to be still alive until its goal is achieved.

Hizb ut-Tahrir is an Islamic movement that has gone through this kind of contest between states. As a global movement, which advocates for the revolutionary change of the current modern state system, Hizb ut-Tahrir is mostly rejected by particularly Muslim majority states, in the Western Asia, Central Asia, and the North Africa; HT was banned, its members were arrested and intimidated. In the western states, HT is often described in negative images like radical and fundamentalist groups although it is not proscribed.

In Indonesia, HT previously was legal and free to organize its activities for more than ten years. The government acknowledged its existence by publishing licenses to HT as a legal social organization in Indonesia. However, in 2017, Indonesian government changed its policy from accommodating to repressing this group. This article attempts to discuss the state`s strategy or policy to tackle Hizb ut-Tahrir`s influence and political activities in Indonesia using state repression concept in the social movement study.

\section{State Repression on Social Movement}

The concept of state repression is used to describe how the state attempts to deal with, contain, or even to kill or demobilize the political contention of social movements. According to Davenport (2005), "state repression means that actions were taken by authorities against individuals and/or groups within their territorial jurisdiction that either restrict the behavior and/or beliefs of citizens through the imposition of negative sanctions" (Honari, 2017, p. 3). The state repression in this sense is deemed natural as a mechanism for the state to counter or eliminate domestic challenges; to create specific political-economic arrangements; and to sustain domestic order or existing political-economic arrangement (Davenport, 2007).

Scholars have tried to identify the systemic factors that contribute to state repression, which state is more repressive, democratic or non-democratic state. Non-democratic state tends to be more repressive because of the natural character of non-democratic states which prefers to organize their societies via directive and force; authoritarian leader relied heavily upon coercive agents; non democratic states are always unstable that potentially invoke resistance and rebellions, as a result the leaders will be always in insecure condition where it then become a need to act in repressive ways (Das, 2017). On the other hand, democracy provides space for non-violent forms of dispute resolution by way of political parties and elections. Efficient democracy also offers the means for the people to expel from office a potentially violent dictator. Democratic states can also use non-coercive measures-reforms/ concessions-to meet internal opposition challenges. The more liberal a country is, the less violence can and is likely to take place. The liberal state protects not only civil liberties and fundamental political rights but also economic freedom (Davenport, 2007).

There are so many kinds of challenges that can endanger state existence and capability in which state needs to respond repressively; riots, demonstrations, guerrilla warfare, terrorism and civil war. Moreover, the scale of state repressive in responding to the challenges relied on the action taken by those challenges. But if challenges do not exist then there will be no repression. After all, state repression is a normal thing for a state to keep and maintain its main responsibilities to its people and its sustainability (Davenport, 2007). 
Scholars have tried to categorize the strategies and activities carried out by a state to understand how the state responds to the challenges it faces. There are some ways that state always carries out to tackle the existing challenges: electronic surveillance, the use of agent provocateurs, physical harassment, mass arrest, political banning, torture, targeted assassination and genocide. These are just some examples the state often uses in responding to the 'illegal' challenges within its domestic politics. In brief, the state does anything that is relevant and effective to diminish the influence or to kill the challenges.

The state repressive policies was categorized into conditional repression and institutional repression. These terms not only describe the state activities but also the time, the target and the effects of the state repression. Conditional repression targets individuals and populations in sporadic and unexpected action or situation through coercive actions. The effect of this strategy is to decrease the individuals or movement's mobilization. Whereas, Institutional repressions target groups or populations structurally and systematically to close the political opportunity for the group to move for a long time. It can involve legal restriction or political banning to hamper the movement's access to formal institutions (Brown, 2008)

Jules Boykoff in 2007 described the steps of state repression to demobilize the movement in more detail by classifying the repression tactics of all countries. Boykoff argues that in fact all mechanisms run by the state are actually a grouping of mechanisms which he divides into two steps, namely dynamic mechanisms and decision mechanisms that involve emulation. The first step consists of four dynamic mechanisms: 1) Resource Depletion, 2) Stigmatization, 3) Divisive Disruption, and 4) Intimidation.

Through resource depletion, the state tries to weaken the capacity of social movement so as to decrease the ability to get involved in collective action. It relates to hampering resources, manpower or material power that belongs to social movement. Many actions the state can undertake in this mechanism such as direct violence, public prosecutions and hearings, arrest and extraordinary rules and laws. Through these actions a movement can be distracted from its main goal to exhaust its capacity in dealing with state policies and actions (Boykoff, 2007).

According to Boykoff, stigmatization is a mechanism "whereby discrediting attributes are attached to the character, nature, or reputation of an individual or group based on perceptions of that individual or group". It will affect or weaken the sense of collective identity of individuals who are in a movement that can discourage individuals to take part in a collective action. Stigmatization will put a social movement on the defensive, on the ever-unfolding path of self-explanation, justified backtracking and damage control. Furthermore, the effect of stigmatization is to hinder the confidence (self-esteem) of the movement's members, challenge solidarity maintenance efforts, complicate recruitment and the process to get support from the public become more difficult. Using mass media is an important medium to construct negative framing and to discredit movement or people who join the movement.

Divisive disruption means social movement is bound by shared beliefs, tactics and goals. However, it can change if there is a changing perception among the members of the movement that can come from inside or outside. State can play its role through infiltrating its agents to create conflict within social movements through surveillance, black propaganda, or provocation. The strategic goal of this mechanism is to reorient the relation between 
movements from cooperation to solidarity to suspicion and mistrust. It then diverts social movements from pursuing the main goal while they are forced to overcome division or conflict within and between groups. It becomes much more difficult for social movement, when the conflict turns into violence or becomes harder then covered by the media, and state agents used it to create negative framing for social movements (Boykoff, 2007).

Moreover, intimidation aims to discourage individuals to join in a collective action of social movement. It can involve direct or indirect threat from the state such as arrest, prosecutions, employment deprivation, including issuing extraordinary rules and laws. Intimidation is a mechanism opted by the state so as to make individuals seriously consider the consequence of taking part in a contentious politics. This also can take the social movements away or distract from its main goal to look internally on the consequence of its beliefs and actions (Boykoff, 2007).

Those are the mechanisms that involve an isolation mechanism taken by the state to inhibit social movement's contentious politics. This mechanism can affect and weaken all elements of social movement: organizational structure, framing process, political opportunity and mobilization process. If these mechanisms work, then it can demobilize, kill or end the existence of social movement, but if it does not work, the result will also be different.

The second step that follows the isolating mechanism is the decisional mechanism that involves emulation as the main mechanism. Emulation means the process of transferring the effect of repression to other individuals, places or movements. When repression is taking place to one social movement, other social movements and individuals will watch and consider the effect of the repression. If groups or individuals decide to step back and cease on contentious politics, then others will also imitate it after considering the situation and the future effect of dissident action (Boykoff, 2007).

The government also can use other hand to repress social movements such as by creating a good environment for vigilant groups or counter movement to repress opposition movement without stopping, condemning or even punish the counter movement that prosecute the opposing movement. In this case, the government prefers to be silent, and not produce any policy to stop repression carried out by counter movement or vigilante groups (Luders, 2003).

The study on Hizb ut-Tahrir globally is growing now whereby many scholars have tried to analyze this group through many perspectives. However, in many works, this group was mostly discussed through descriptive analysis approach. This was the same approach with the mainstream study of political Islam that mostly studied on its ideology, structure of organization, goals and the history of that Islamic movement (Wiktorowicz, 2004). Another dominant approach is by using the international security perspective or security oriented analysis that explained political Islam from the issue of terrorism and violent (Hadiz, 2010).

Works that specified analyzing Hizb ut-Tahrir from social movement studies are now being developed some scholars have tried to do this such as Michael Karagiannis (2006) studied especially on Hizb ut-Tahrir in Central Asia, Uzbekistan, Kyrgyzstan, and Tajikistan by using structural-functional theory, resource mobilization theory, political opportunity theory, and framing theory (Karagiannis, 2006). On the other hand, Mohamed Nawab Mohamed Osman`s work on Hizb ut-Tahrir particularly focused in South East Asian 
countries, Indonesian and Malaysia (Osman, 2009). Muhammad Iqbal Ahnaf (2009) analyzed the changing of HTI revolutionary character to be more moderate using the concept of refolution - combination between revolution and reformation (Ahnaf, 2009).

At present, there are many works and literature that try to explain the dynamics of the Islamic political movement through the lens of social movements. Especially for Hizb utTahrir, this group has also begun to get wider attention in the academic research agenda. Looking at Hizb ut-Tahrir, there is still little research that tries to analyze this Islamic political group from the lens of social movement approaches. Hence, this study is one contribution to develop the study of social movement on Islamic political movements, more specifically on Hizb ut-Tahrir in Indonesia.

\section{Methods}

This study used case study research in social science research method whereby taking a specific issue in the social movement study to apply in the Islamic political movement phenomena. There are varied approaches and issues in social movement that can be elaborated such as structural functional approach, framing theory, mobilization theory, political opportunity theory and etc. This study focuses on the issue of relation between state and social movement by using concept, state repression. This concept then will be applied in discussing the topic of the state response to Hizb ut-Tahrir in Indonesia.

To collect the data, this study used mainly literature work that is through finding out the relevant references that support the data needed in this study such as the history of Hizb utTahrir in Indonesia (HTI), the state response to HTI and the concept that is used to analyze the object of the study, the concept of state repression. These all references can be found in the internet through searching state official websites and documents, news websites, books and journals. The data collection then is classified based on each sub topic that is needed to ease the writing process of this article. Explanatory approach is used to implement strategies of Indonesian government to repress HTI.

\section{Result and Discussion \\ Hizb ut-Tahrir Indonesia}

Hizb ut-Tahrir (the liberation party) was found by Sheikh Taqiyuddin an-Nabahani (1909-1977), an Islamic scholar and judge. This group was first declared in Jordan and officially registered with the Jordanian government in 1953 and later expanded regionally in Arab countries then reached to more than 40 countries globally with around millions of members (Malik, 2004) (Rodhi, 2012).

As an Islamic political movement, Hizb ut-Tahrir (HT) seeks to change the current modern system in the Muslim world from a secular system to an Islamic system. HT believes that the root cause of the modern state, especially in the Muslim world, is the adoption of secular systems such as democracy, liberalism and human rights in social, economic and political life. To solve all Muslim problems, according to HTI, Muslims must change the existing system into an Islamic political system that applies all aspects of Islamic law. HT believes that the only system accepted in Islam is the Khilafah system, a system inherited by the Prophet Muhammad and his companions (Hizb ut-Tahrir, 2005). 
To change the secular system, HT argued, to follow the method of the prophet in political change that is through intellectual and political activities, without resorting to violence. Based on the interpretation of the prophet method, HT concluded there are three steps to change political condition, first, the culturing process, second, engaging with people to win their hearts and minds as well as to cut people's loyalty to the state and political system. Third, establishing a state that applies Islamic sharia law (Hizb ut-Tahrir, 1999).

HT's hostility towards the secular political system and the call for Islamic law and the Islamic state are the main narratives for this group in its action. This then became controversial among Muslims, where many chose to support this group, and many also condemned and opposed it. Regarding the state's response to HT, this group has experienced various kinds of state oppression, including arrest, murder and stigmatization in many countries, especially in Muslim and Arab countries (Aswar, 2018).

HT began working in Indonesia in the 1980s brought by Abdurrahman al-Baghdadi. During the 1980s and 1990s, Hizb ut-Tahrir activists worked primarily in Indonesian universities through Islamic student organizations then grew wider in the Indonesian community. In 2000, HT openly declared his work and ideas in Indonesia by holding the first International Khilafah Conference, which was attended by around 2000 people. It was then followed by intensive contact with the Indonesian people through various events and programs including producing media, talk shows, demonstrations and international conferences. All of these events were tools for Hizb ut-Tahrir to engage with Indonesians and to introduce the idea of sharia and the caliphate (Muhtadi, 2009).

Since the early 2000s, the state had accommodated Indonesian Hizb ut-Tahrir (HTI) and considered it as a normal social Islamic organization in Indonesia. Even, state had granted registered status to HTI since 2004 and again legal status (Badan Hukum Perkumpulan) in 2014. This legal status was actually a blessing to HTI in Indonesia compared to other states that mostly ban this group. Furthermore, HTI also had a good relation with other Muslim groups in Indonesia seen by HTI executive members served as members of the Indonesian Ulema Council, 2005-2010 (MUI - Majelis Ulama Indonesia). As a result of this, HTI was able to socialize its ideas to get support and to recruit new members through many mediums and places (Ilhamdi, 2015).

The state perception toward HTI changed after the Ahok issue, when HTI became involved in a movement that finally defeated Ahok and put him in jail for religious blasphemy. It started in 2016, when Ahok mentioned an issue relating to the Koran and politics that led many people condemned his statement and considered it as a blasphemy against Islam and thereby violating Indonesian law. Afterwards, protest and demand for arresting Ahok sparked all around Indonesia. As a result, this movement succeeded to put Ahok in jail, and also was proved successful to defeat Ahok in the gubernatorial election 2017 (Warburton \& Aspinall, 2019).

\section{State Repression on Hizb ut-Tahrir in Indonesia}

The state starts to take a repressive action toward a social movement after it perceives there is a potential or actual threat to the state. In repressing a certain movement, the state can choose many kinds of actions in order to tackle the movement's influence or to end it. With 
regard to the state repression to Hizb ut-Tahrir in Indonesia, the state used mainly three strategies namely, resource depletion, stigmatization and intimidation.

The defeat of Ahok in 2017 and the increase of Islamic mobilization in Indonesian politics were seen by the regime as the rise of Islamic radicalism threat to Indonesian politics. That was perceived by the state to threaten Indonesian unity, nationalism and ideology (Pancasila) (Valdameri, 2017). Based on this rationale the regime started to take a coercive or repressive approach to those "radical" groups and movements. Especially, for the Muslim figures and activists, some of them were prosecuted by the government with an issue not related to their actions, such as Habib Rizieq Shihab (FPI-Islamic Defender Front Leader) was investigated for allegedly insulting Pancasila; making and spreading pornographic chat; Munarman, FPI Secretary General was declared a suspect in a case in which he had supposedly slandered a Balinese militia; Bachtiar Nasir was investigated for money laundering, while the chairman of the Islamic Community Forum (Forum Umat Islam, FUI), the former HTI leader Al-Khaththath, was also arrested for attempted rebellion (IPAC, 2018).

Regarding Hizb ut-Tahrir, the state takes an action to revoke the legal status or to dissolve this group in Indonesia by creating an extraordinary law as a mode of action that aims to tackle the mobilization capacity of this group`s human or material resources (resource depletion mechanism). Before this group was finally dissolved in July 2017, in March and April there was an increase of opposition from NU military wings, Banser and GP Anshor, of the event that was routinely held by HTI every year, commemorating the demolish of Ottoman Caliphate in 3 March 1924, or in Rajab. Basically, NU`s wings opposition to HTI`s started in 2016 when HTI held an even called Muktamar Tokoh Umat $1437 \mathrm{H}$. This event was stopped and protested by Nahdlatul Ulama`s members and Banser mainly in the area that dominated by NU`s members in the eastern part of Java such as in Jember, Kediri, Jombang, Magetan, Surabaya, Tulungagung, and Bojonegoro (Firdaus, 2016).

Opposition continues in 2017, even became colossal and national. In 2017, HTI again held an event through a long march entitled "Masirah Panji Rasulullab" or the march of the Prophet's Flag, which aimed to introduce the Prophet Muhammad's flag. The event was held in all provinces in Indonesia, and cities from April to May 2017. In many places, Banser had also been preparing to mobilize hundreds of its members to block and stop the event. As a result, in many places HT`s event was canceled by the security forces or HTI changed the venue due to pressures and threats from Banser. Some of the main places where Banser faced HTI were in Semarang (Central Java Province), Bandung (West Java Province), Makassar (South Sulawesi Province), Surabaya (East Java Province), Yogyakarta Province, and Jakarta. Banser actually did not act alone to contain HTI, but also supported and allied with other NU bodies such as youth organizations and NU students such as IPPNU, CBP IPNU, PMII, and GP Ansor.

The demand to dissolve Hizb ut-tahrir and the opposition of the members of Nahdlatul Ulama in many places in Indonesian were responded and supported by the government through initiating to create a regulation in lieu of law (Perppu - Peraturan Pemerintab Pengganti Undang Undang). This Perppu is said to change the previous social organization law, No. 17 of 2013 (UU Nomor 17 tahun 2013). The government argued that the existing law was not sufficient anymore to prevent the spread of ideology that against Pancasila and the 1945 constitution, both from the substantive aspects related to norms, prohibitions and sanctions as well as existing legal 
procedures. Again, the existing law, 2013 also was said, it was not fulfilling of the contrario actus, administrative law principle that the institution that issues licenses or gives authorization, it is the institution that should have the authority to revoke or cancel it. Furthermore, the understanding of teachings and actions that were contrary to Pancasila was narrowly formulated in the 2013 law, that was only limited to the teachings of Atheism, Marxism and Leninism. In fact, many other teachings can also replace and contradict with Pancasila. This perppu was issued on the 12 of July 2017 (Fakhri, 2017).

In general, the government perceived that the existing law, 2013 societal organization law still had many shortcomings and was inadequate to solve a threat immediately. This issue then created a legal vacuum that had to be solved not through making a new law that needed a long period of time. Hence, the government decided to issue a presidential decree as the best solution to a condition that was needed to resolve conditions immediately (Kuwodo \& Erdianto, 2017). Only seven days, on 19 July 2017, after the Perppu was issued, the Indonesian Ministry of Law and Human Rights (KEMENKUMHAM) declared to revoke the legal status of HTI. HTI was considered to not carry out a positive role to take part in the development process in order to achieve national goals. HTI also was strongly indicated to have been contrary to the objectives, principles and characteristics based on the Pancasila and the 1945 Constitution of the Republic of Indonesia as stipulated in Law Number 17 of 2013 concerning Mass Organizations. Again, the activities carried out by HTI were considered to had caused conflicts in the community that could threaten the security and order of the community, as well as endangered the integrity of the Unitary Republic of Indonesia (Erdianto, 2017).

The government also admitted that HTI was registered at the Ministry of Law and Human Rights as a legal entity of the association with registration number AHU00282.60.10.2014 on July 2, 2014. But after the revocation of the HTI legal entity, the organization was declared disbanded in accordance with the decree, Number 2 of 2017 Article 80 A. The government also pleased those who objected to the decision, including HTI, to take legal action in accordance with the provisions of the legislation (Ghoida, 2017).

Through the logic of emergency conditions and inadequacy of law and at the same time there was an imminent threat of HTI in Indonesia, the government then had the legitimacy to dissolve HTI in a very quick way. The presidential decree was issued on the 12 of July then HTI was dissolved on the 19 of July using the decree. If the government did not make the decree, the process actually would be very long like mentioned in the 2013, social organization law (UU Ormas) that an organization that is proved to violate the law would be treated persuasively by the government before being given administrative sanction or punishment. The administrative punishment according as follows; 1) Sending the letter of warning, 2) Stopping the state financial assistance, and 3) Revoking the letter of register or the legal status as legal agency (badan bukum).

According to the law, in the first step, the government has a right to send a letter three times to an organization before deciding to step to the next sanction. Each letter will take 30 days to see the response of an organization. It means the government needs around 90 days or 3 months to send letters before going to next sanction. If the letter fails to change the attitude of an organization, the state can stop the activities and stop the financial assistance of an organization maximum six months. If still fails, then the government can take the final step that is revoking the "registered status" or legal status of an organization. But this final step should be 
through district court by attorney after being requested by the minister that manages the law and human right affairs. And the court has a maximum of 60 days to issue a final result (UU Ormas, No. 17/2013, 25-29).

This very long step to revoke an organization then became an obstacle to the government to respond to the imminent threat of HTI. After coordinated mainly by the general attorney, then the government chose to issue a perppu, which was considered as a constitutional way in responding to an emergency situation. The government referred to the law of danger situation (UU Tentang Keadaan Bahaya), Number 23, 1959, chapter 22, verse 1 that mentioned, "Dalam Hal ihwal kegentingan yang memaksa, presiden berhak menetapkan peraturan pemerintah sebagai pengganti undang - undang" or in matters of urgency, the president has the right to set government regulations in lieu of laws.

Furthermore, the explanation of the urgency matters was expounded in the decision of the Constitutional Court of the Republic of Indonesia Number 138/PUU-UI/2009 mentioned three conditions must be explained in terms of compulsive matters, which are as follows; 1) There are circumstances namely the urgent need to resolve legal issues quickly based on the law; 2) The required law does not yet exist so there is a legal vacuum, or there is a law but it is not adequate; 3) The legal vacuum cannot be overcome by making the law in the usual procedure because it will require quite a long time while the urgent situation needs certainty to be resolved (Perppu Ormas 2017, 3).

After the presidential decree was issued, some chapters were changed and added, mainly the point regarding kind of sanctions, procedures of giving sanctions and the body that has a right to impose it. In the previous law of social organization, 2013 mentioned that administrative sanction was the only kind of sanctions that was imposed on a social organization, but in the presidential decree, it was added that not only administrative but also criminal sanction. Administrative sanction was for the organization whereas criminal sanction was for the members (Perppu Ormas 2017, 4).

Regarding the government body that deserves to revoke the legal status of an organization, according to the previous law, 2013 the right was on the hand of district court after being proposed by the ministry of law and human rights, but in the decree the authority changed to exclude the role of district court and to give authority for the ministry of law and human rights to decide it (Perppu Ormas 2017, 5). The time for every step of administrative sanction was also shortened from 30 day for every letter of warning to only seven days and there was only one step of sending a letter (Perppu Ormas 2017, 5). Again, this new law put new points that once the legal status of an organization is revoked then the organization is also automatically dissolved (Perppu Ormas 2017, 7).

\section{Controversy of The State Policy}

After the government signed the decree and made HTI as the first organization that punished through the decree, it became controversial in Indonesia and became a serious issue and debate among Indonesian people. For those who supported the state policy, they had the same argument that HT posed a serious threat to Indonesian politics. HTI was said to bring an ideology, which was not only against Indonesian ideology, but also potentially created a clash within society. The statement to support state policy had been showed by Muslim groups in 
their declaration on June 2017 where around 13 Islamic social organizations (Ormas) that allied in the Friendship Organization of Islamic Organizations (LPOI - Lembaga Persahabatan Ormas Islam) gathered and declared their support for the government to dissolve Hizbut Tahrir Indonesia. The thirteen Islamic organizations were Nahdlatul Ulama, Islamic Unity (Persatuan Islam), AlIrshad Al-Islamiyah, Mathlaul Anwar, Ittihadiyah, The Association of Indonesian Chinese Muslim (PITI - Persatuan Islam Tionghoa Indonesia), Ikadi, Azzikra, Indonesian Islamic Society (Syarikat Islam Indonesia), Alwashliyah, Tarbiyah Islamiyah Association, Persatuan Umat Islam (The Unity of Islamic Ummah), UMI and HBMI (Alawi, 2017).

On the other hand, many figures and activists opposed this policy. The issue was actually not focusing on HTI but the process to dissolve an organization by using presidential decree and changing many chapters in the previous law, Social Organization law, 2013. The figures that opposed this presidential decree came from legislative members, political parties, human rights activists, and law and political observers. Mostly those who criticized the government argued that using a special law to dissolve an organization is not needed even if it would make Indonesian democracy to regress. The existing law was considered enough to respond to Hizb ut-Tahrir Indonesia.

According to Fahri Hamzah, a deputy chairman of the legislative (2014-2019) from the party of Justice and Prosperity (Partai Keadilan Sejahtera) that a state should function as a facilitator for social organization in Indonesian. So, if there was a problem with an organization, the government should dialogue with them, and if considered to dissolve, the government must go through a judicial process. Making a presidential decree to respond to HTI was seen as excessive and showed the failure of the state as a facilitator of social movements (Sarwanto, 2017). Also, Fadli Zon, (the deputy chairman of the legislative 2014-2019) from the party of Gerindra, called the Perpu 2017 as the new kind of dictatorship which once the state followed this step to HTI could also be used arbitrarily to other groups or parties (Ihsanuddin, 2017b). The same critic also came from other political parties such as Partai Amanat Nasional (PAN), and Partai Keadilan Sejahtera.

Yusril Ihsan Mahendra, Irman Putra Sidink, Refly Harun, the three Indonesian prominent law observers had the same opinion that responding to HTI should be through the due process of law. According to Yusril, there was no sufficient reason to conclude that HTI brings emergency situations to Indonesia that would be responded to through special law. Even, abolishing the judicial process and procedures that were arranged in the law UU Ormas 2013, was considered to be a setback for Indonesian democracy. Based on the new law, the state could choose to dissolve any organization arbitrarily for the state political interest (Ihsanuddin, 2017a).

For Irman, the arguments that postulated by the government to respond HTI were actually not sufficient for two reasons: the first is chapter 59, verse 4 in UU Ormas that mentions that Ormas is prohibited to develop, adhere, and teach understanding that was contrary to Pancasila. The definition of understanding that was contrary to Pancasila in the Ormas Law was as in the explanation of norms, atheism, communism, Marxism, and Leninism. So, teachings that were outside the teachings mentioned did not conflict with Pancasila and therefore could not be subject to sanctions.

According to Irman, the purpose of the issuance of the Perppu was to fill the legal vacuum in order to bring legal certainty. So the most important guarantee was whether after the 
issuance of the Perppu would provide legal certainty or not. He explained, if the Perppu was in fact increasingly providing legal uncertainty, it could be ensured that the Perppu did not meet the conditions of urgency. In fact, according to Irman, the Perppu could turn into an instrument of abuse of authority by the Government.

Moreover, the phrase used by the government to dissolve HTI that was considered wanted to change Indonesian ideology and constitution was too broad in definition and had multiple interpretations. Because it could affect all groups that positively wanted to contribute to improve Indonesian constitution such as communities that concern on constitutional studies. At the end, this Perppu presented legal uncertainty and at the same time it became unconstitutional. This argument was also used by Refly Harun to rebut the logic of the state legitimacy for making the Perpu 2017 (Harun, 2017).

The principle of contrarius actus that granted the ministry of law and human rights to revoke the legal status of a social organization was also criticized because it negated the role of judicial power. According to Irman, the existence of judicial power was a logical consequence of the principle of the Indonesian state as a rule of law. The emergence of judicial authority in the Ormas Law is a necessity of the constitution, because the principle of the rule of law where there is recognition of human rights, freedom of association that cannot be reduced, limited, and subjectively revoked by the president (Huzaini, 2017).

Many activists and figures also hardly opposed this perpu 2017 as the way to dissolve HTI, such as the Alliance of Independent Journalist - Aliansi Jurnalis Independen (AJI), the Indonesia Legal Aid Foundation - Yayasan Lembaga Bantuan Hukum Indonesia (YLBHI), Amnesty International, Human Right Watch, Komnas HAM (Human Rights National Commission), and Hamdan Zoelva (The Former Chairman of Constitutional Court). The main argument of those activists to object to the Perppu 2017 was because it violated the principle of human rights of the freedom of association and expression, which was written in the International Covenant of Civil and Political Rights that was signed and adopted by Indonesia in 2009. Also, this perppu was said to contradict the 1945 Constitution itself, which is stated in Article 28 of the 1945 Constitution, "the freedom to associate and to assemble, to express written and oral opinions, etc., shall be regulated by law". Article $28 \mathrm{E}$ of the 1945 Constitution number (3) states "every person shall have the right to the freedom to associate, to assemble and to express opinions".

Those activists also argued that the banning of an organization should be the last resort, and the state should find other ways before deciding to take a hard approach. And the process of banning an organization should be in accordance with law and contested in the court (Harsono, 2017). Andreas Harsono from Human Right Watch and Asfinawati, the head of YLBHI, both said that the right solution to respond to HTI was that not banning but criminalizing all of its and its member's violence actions and hate speeches (Asfinawati, 2017).

Critics also came from many foreign scholars like Vedi Hadiz, Liam Gammon, Tom Power, Sidney Jones, and Gregory Fealy. Those scholars warned that what the state did to respond to Hizb ut-Tahrir was actually the regression of Indonesian democracy and not really for legal need but very political. According to Fealy, there were no enough arguments to take decision for banning HTI; in fact there was no real and explicit rejection of the Indonesian state ideology, Pancasila from HTI leaders or members. Also, HTI had no history of doing violence, 
unlike FPI (Islamic Defender Front) that was repeatedly involved in some violence actions. Lastly, HTI had never created social disturbance as being accused by the government. Commenting the prior announcement of Dissolution of HTI, in May, where HTI was in physical confrontation with NU, Fealy said that it was an organized agenda that coordinated between state and NU to fight against HTI. Fealy said, "Interviews with NU leaders suggest some level of coordination between NU's youth wing, Ansor, and Jokowi government officials, seemingly to build a case for action against HTI' (Fealy, 2017).

Beside criticizing the government approach to repress Hizb ut-Tahrir in Indonesia, many observers also argued that the legal and security arguments of the state was not really the true reason of the state to ban HTI. Many contended that the hard policy toward the Islamic movement in Indonesia was actually the panicky response of Jokowi`s regime after the defeat of Ahok as his ally in the 2016 gubernatorial election. HTI was said to be one victim of the state's revenge and like other figures who were criminalized by the state (Power, 2018) (Suganda et al., 2010).

Muhammadiyah as the second largest Islamic social organization in Indonesia also did not involve supporting the method of state to dissolve HTI. It even rejected the state policy that made a special law. Muhammadiyah contended that the existing 2013 law is enough if the state had encountered a problem with a certain organization and it should be through judicial process in the court. Even, the Perppu 2017 was considered as unconstitutional and against the principle of democracy (Fachrudin, 2017).

Regarding to Indonesian Ulama Council (MUI), this state independent body was actually one most important thing in deciding either or not an organization as considered having a misleading understanding of Islam. On the issue of HTI, MUI did not see any false understanding of HTI on Islam that deserved to call it as misleading group. But politically, as HTI was considered to have a radical ideology, MUI`s position was just pleasing the government to take a step based on constitutional means. At this point, MUI seemed to be more careful and neutral. Support to dissolve HTI from MUI mainly came from members affiliated with Nahdlatul Ulama, including its chairman, Ma`ruf Amin (Hakim, 2017).

\section{After The Perppu 2017}

The increase of Islamic mobilization and the Islamic narratives in Indonesian politics was responded by the state through formulating a systematic and institutionalized policy to contain this threat. Since 2016 until president Jokowi was elected in the 2019 presidential election, the issue of radicalism had become a foremost issue that was seriously responded to. Below are some policies and actions undertaken by the government since 2016 until today to tackle the rise of Islamic radicalism in Indonesia.

Firstly, the government has increased the anti Islamic radicalism narratives as the threat to Indonesian state and ideology. This propagation was disseminated through many forums and interviews by the president or his ministers. Also, the government insisted the need to strengthen Indonesian ideology; unity and diversity in Indonesian daily life (Republika, 2017). The impact of this anti radical propaganda to Indonesian is that there were widespread rejections of certain 
Islamic preachers who were considered that spread the idea radicalism and support HTI especially to preach in Friday prayer or taraweeh prayer in Ramadan.

Secondly, after the dissolution of HTI in 2017, the ministry of Research, Technology and Higher Education announced to all civil servants and lecturers who joined HTI to choose either still in HTI or resign from their job. The university leaders responded to this by collecting the data of their lecturers who joined HTI (Juniari, 2017). Then In 2018, some lecturers in several Indonesian universities were investigated because of allegedly being considered to support HTI. This follows the reports of some Indonesian agency; counter terrorism agency (BNPT) and national intelligence agency (BIN), that many Indonesian universities have been infiltrated by the idea of radicalism (Sumandoyo, 2018). Thirdly, in 2018, through the ministry of religious affairs, the government released the list of moderate Islamic preachers, which mostly exclude the main figures who were known as the regime political opposition (Ihsanuddin, 2018).

Fourth, after winning the election in 2019, and inaugurated on October 20, 2019, Joko Widodo appeared to be more intensive in combating Islamic radicalism in Indonesia by appointing several military and police officers in his cabinet such as Tito Karnavian, a former police chief who holds a $\mathrm{PhD}$ in terrorism and had led the country's counter terrorism forces (Densus 88), as interior minister. Jokowi also gave the post of minister of religious affairs to Fachrul Razi, a former military general. There was also the Coordinating Minister for Political, Legal and Security Affairs Mahfud MD who was once facilitated as a member of the Steering Committee of the Pancasila Ideology Development Board (BPIP).

Once this cabinet was formed, the first agenda on the fight against radicalism was to issue a joint ministerial decree signed by 11 ministries and heads of state agencies to prohibit civil servants from expressing opinions on social media containing "hate speech" against Pancasila, the 1945 Constitution, the state motto of Bhinneka Tunggal Ika (Unity in Diversity), Unitary State of the Republic of Indonesia (NKRI) or the government. Also, civil servants could face sanctions for liking tweets containing hate speech, or for attending events that spread hate speech. A website has been set up to allow the public to report on civil servants who support radical ideas (Hermawan, 2019).

Furthermore, the new government also seems to fight against radicalism deeper and broader in the level of society. Many narratives expressed by the state that eager to neutralize Islamic boarding school (pesantren), Mosques, Majelis Taklim (The ministry of religious affairs even issued Regulation of the Minister of Religion, Number 29, 2019, which requires Majelis Taklim to register officially), early childhood education level (Pendidikan Anak Usia Dini PAUD) and elementary school level (Sekolah Dasar - SD) from the radical ideas and doctrines. On the other hand, the religious ministry has issued a policy to change the topic of Khilafah and Jihad in the Islamic school textbooks as considered as not relevant in Indonesian contemporary life that built upon Pancasila and the 1945 Constitution (Cnnindonesia, 2019).

From the state point of view, Hizb ut-Tahrir and its ideology brought a threat to Indonesian politics. Hizb ut-Tahrir pursued to change the existence of the modern political system and worked within Indonesian society to persuade people to change their loyalty from state ideology to Islamic ideology. Moreover, the threat increased mainly after the issue of Ahok`s religious blasphemy in 2016. As a result, the state reacted by repressing the Muslim figures including Hizb ut-Tahrir Indonesia. There were three main strategies of state in 
repressing HTI namely through issuing extraordinary law called as Perppu Ormas 2017 which aimed to break man and material resources of HTI so as to weaken this group's capacity to mobilize in political action. The effect of this policy to HTI was that this group had no more state legitimacy to do their action in Indonesian territory, because after this policy issued automatically this group no longer exists.

The second strategy of state action was stigmatization in which the state tried to create negative framing or narrative to HTI so as to weaken the sense of collectivism of this group as well as to put this movement in a defensive position. In doing this, state frequently reproduced the narrative that Hizb ut-Tahrir was an "Ormas Radical Anti Pancasila", or Radical and Anti Pancasila group that endangered Indonesian political unity. This narrative at the same time became the main legitimacy of the state to dissolve Hizb ut-Tahrir Indonesia. Intimidation mechanism was another strategy of state to repress this group where state warned all the civil servants to not join or support radical groups, once they do that state could impose sanction such as would be dismissed from job or prosecuted. All of these three mechanisms used by the state to weaken Hizb ut-Tahrir`s ability to work in Indonesia until it had no more power to work in Indonesian society.

\section{Conclusion}

For over 20 years, HTI had worked to persuade Indonesian people to accept the religious and political mission of HTI. Many events were held to disseminate HTI`s ideas such as seminars, conferences, talks, demonstrations, magazines, leaflets, books, including online media. As a result, thousands of people joined Hizb ut-Tahrir Indonesia and attended its events. Globally, HT is known as a radical Islamic group that pursues to establish the Islamic khilafah state as the only state in the Muslim world and throwing away the existing secular system that is considered as the root cause of all problems in the Muslim world. This radical stance on Islam and the modern ideologies places this group in conflict with all Muslim states where many states face this group coercively including Indonesia.

In responding to HTI, the state used three kinds of actions namely: the issuance of an extraordinary law known as Perppu Ormas in 2017 to dissolve this group. According to the state, HT failed to show its contribution in Indonesia life indeed it brought an ideological threat to Indonesia; stigmatizing HTI through producing negative frames or narratives such as radical, dangerous and anti Pancasila; intimidating the state`s civil servant who support and join HTI will get punishment from the state. All these strategies were taken by the state to weaken this group`s ability to work further for puruing its political and ideological goal. However, the state response does not always work as the state hopes, for some cases it does but sometimes state repression strengthens groups or movements. Scholars in the study of social movement have largely studied the impact of the state repression on social movement. I have also discussed specifically on this issue "the impact of state repression on HTI" in my other works.

\section{References}

Ahnaf, M. I. (2009). Between revolution and reform: The future of Hizbut Tahrir Indonesia.

$\begin{array}{llll}\text { Dynamics of Asymmetric } & \text { Conflict, } & \text { 2(2), } & \text { 69-85. } \\ \text { https://doi.org/10.1080/17467580902822163 } & & \end{array}$


Alawi, A. (2017, June 1). Ormas-Ormas Islam Indonesia Dukung Pemerintah Bubarkan HTI. Retrieved October 14, 2020, from nu.or.id website: https://www.nu.or.id/post/read/78453/ormas-ormas-islam-indonesia-dukungpemerintah-bubarkan-hti- $\% 0 \mathrm{~A}$

Asfinawati, A. (2017, May 15). Pandangan HAM soal Pembubaran Hizbut Tahrir - Kolom majalah.tempo.co. Retrieved October 14, 2020, from majalah.tempo.co website: https://majalah.tempo.co/read/kolom/153147/pandangan-ham-soal-pembubaranhizbut-tahrir?

Aswar, H. (2018). What is Wrong with Democracy? A View from Hizbut Tahrir. Jurnal Transformasi Global, 4(1), 57-64.

Boykoff, J. (2007). Limiting Dissent: The Mechanisms of State Repression in the USA. Social Movement Studies, 6(3), 281-310. https://doi.org/10.1080/14742830701666988

Brown, H. E. (2008). Repression, mobilization, and social policy: The Virginia civil rights movement and the War on Poverty. Research in Political Sociology, Vol. 17, pp. 135-173. https://doi.org/10.1016/S0895-9935(08)17006-1

Cnnindonesia. (2019, December 8). Kemenag Revisi Konten Khilafah dan Jihad di Buku Madrasah. Retrieved October 14, 2020, from cnnindonesia.com website: https://www.cnnindonesia.com/nasional/20191208191551-20-455193/kemenagrevisi-konten-khilafah-dan-jihad-di-buku-madrasah

Das, R. J. (2017). Social Movements and State Repression in India. Journal of Asian and African Studies, 52(8), 1080-1102. https://doi.org/10.1177/0021909616653258

Davenport, C. (2007). State Repression and the Domestic Democratic Peace. Retrieved from https://www.cambridge.org/core/books/state-repression-and-the-domesticdemocratic-peace/DBD252D901E3050F5062B615D760F345

Erdianto, K. (2017, May 8). Ini Alasan Pemerintah Bubarkan Hizbut Tahrir Indonesia. Retrieved October 14, 2020, from nasional.kompas.com website: https://nasional.kompas.com/read/2017/05/08/14382891/ini.alasan.pemerintah.buba rkan.hizbut.tahr ir.indonesia

Fachrudin, F. (2017, October 17). Perwakilan Muhammadiyah Minta DPR Tidak Mengesahkan Perppu Ormas. Retrieved October 14, 2020, from nasional.kompas.com website: https://nasional.kompas.com/read/2017/10/17/23004581/perwakilanmuhammadiyah-minta-dpr-tidak-mengesahkan-perppu-ormas

Fakhri, F. (2017, June 12). Ini Alasan Pemerintah Menerbitkan Perppu Nomor 2 Tahun 2017 soal Ormas : Okezone Nasional. Retrieved October 14, 2020, from nasional.okezone.com website: https://nasional.okezone.com/read/2017/07/12/337/1734467/ini-alasan-pemerintahmenerbitkan-perppu-nomor-2-tahun-2017-soal-ormas

Fealy, G. (2017, July 17). Jokowi's bungled ban of Hizbut Tahrir. Retrieved October 14, 2020, from lowyinstitute.org website: https://www.lowyinstitute.org/the-interpreter/jokowis-bungled-ban-hizbut-tahrir

Firdaus, F. (2016, May 2). Pesan GP Ansor: Tak ada pemakluman untuk Hizbut Tahrir. Retrieved October 14, 2020, from rappler.com website: https://www.rappler.com/world/gp-ansor-jombang-hizbut-tahrir 
Ghoida, R. (2017, July 19). HTI Resmi Dibubarkan, Kemenkumham Cabut Status Hukumnya Nasional Tempo.co. Retrieved October 16, 2020, from nasional.tempo.com website: https:// nasional.tempo.co/read/892580/hti-resmi-dibubarkan-kemenkumham-cabutstatus-hukumnya $/$ full\&view $=\mathrm{ok}$

Hadiz, V. R. (2010). Political Islam in Post- Authoritarian Indonesia. CRISE (Centre for Research on Inequality Human Security and Ethnicity, (74), 39.

Hakim, R. N. (2017, July 19). Ketua Umum MUI Dukung Langkah Pemerintah Bubarkan HTI. Retrieved October 14, 2020, from nasional.kompas.com website: https://nasional.kompas.com/read/2017/07/19/14304671/ketua-umum-mui-dukunglangkah-pemerintah-bubarkan-hti\%0A

Harsono, A. (2017, July 19). Indonesia's Ban of Islamist Group Undermines Rights | Human Rights Watch. Retrieved October 14, 2020, from hrw.org website: https://www.hrw.org/news/2017/07/19/indonesias-ban-islamist-group-underminesrights

Harun, R. (2017, October 25). Irasionalitas Perppu Ormas. Retrieved October 14, 2020, from news.detik.com website: https://news.detik.com/kolom/d-3698990/irasionalitasperppu-ormas

Hermawan, A. (2019, November 28). From red to green menace: How "radicalism" becomes the new political bogeyman in Indonesia - Opinion - The Jakarta Post. Retrieved October 14, 2020, from thejakartapost.com website: https://www.thejakartapost.com/academia/2019/11/28/from-red-to-green-menacehow-radicalism-becomes-the-new-political-bogeyman-in-indonesia.html

Hizb ut-Tahrir. (1999). The Methodology of Hizb ut-Tabrir For Making Change. London: Al-Khilafah Publications.

Hizb ut-Tahrir. (2005). The Institutions of State. London: Al-Khilafah Publications.

Huzaini, M. D. P. (2017, October 19). Alasan 3 Pakar Hukum Tata Negara Sepakat Tolak Perppu Ormas . Retrieved October 16, 2020, from hukumonline.com website: https://www.hukumonline.com/berita/baca/lt59e82b8fc2517/alasan-3-pakar-hukumtata-negara-sepakat-tolak-perppu-ormas/

Ihsanuddin, I. (2017a, July 11). Kritik Yusril soal Perppu Pembubaran Ormas. Retrieved October 16, 2020, from nasional.kompas.com website: https://nasional.kompas.com/read/2017/07/11/20521511/kritik.yusril.soal.perppu.pe mbubaran.ormas.

Ihsanuddin, I. (2017b, July 11). Menurut Fadli Zon, UU Sudah Cukup Mengatur Ormas. Retrieved October 16, 2020, from nasional.kompas.com website: https://nasional.kompas.com/read/2017/07/11/20231151/menurut.fadli.zon.uu.suda h.cukup.mengatur.ormas

Ihsanuddin, I. (2018, May 18). Kemenag Rilis Daftar 200 Penceramah yang Dianggap Moderat. Retrieved October 16, 2020, from nasional.kompas.com website: https://nasional.kompas.com/read/2018/05/18/19452091/kemenag-rilis-daftar-200penceramah-yang-dianggap-moderat

Ilhamdi, A. (2015). Gerakan Politik Islam Hiðbut Tabrir Indonesia (HTI): Transformasi Menuju Pengakuan Resmi Pemerintah (2000-2006). Retrieved from 
http://lib.ui.ac.id/naskahringkas/2018-10/S59449-Ilhamdi

IPAC. (2018). After Ahok : the Islamist Agenda in Indonesia. IPAC Report No 44, (44), 25.

Juniari, E. (2017, July 23). Tindak Lanjut Pembubaran HTI, Menristekdikti Kumpulkan Seluruh Rektor - kbr.id. Retrieved October 16, 2020, from kbr.id website: https://kbr.id/nasional/07-

2017/tindak_lanjut_pembubaran_hti_menristekdikti_kumpulkan_seluruh_rektor/912 63.html

Karagiannis, E. (2006). Political Islam in Uzbekistan: Hizb ut-Tahrir al-Islami. Europe - Asia Studies, 58(2), 261-280. https://doi.org/10.1080/09668130500481444

Kuwodo, F. J., \& Erdianto, K. (2017, July 12). Ini Tiga Pertimbangan Pemerintah Menerbitkan Perppu Ormas. Retrieved October 16, 2020, from nasional.kompas.com website: https://nasional.kompas.com/read/2017/07/12/12232051/ini-tig

Luders, J. (2003). Countermovements, The State and The Intensity of Racial Contention in The American South. In J. A. Goldstone (Ed.), States, Parties, and Social Movements (pp. 2743). United State of America: Cambridge University Press.

Malik, S. (2004, September 13). For Allah and the caliphate. Retrieved October 16, 2020, from newstatesman.com website: https://www.newstatesman.com/node/195114

Muhtadi, B. (2009). The quest for hizbut tahrir in Indonesia. Asian Journal of Social Science, 37(4), 623-645. https://doi.org/10.1163/156853109X460219

Osman, M. N. M. (2009). Reviving the Caliphate in Malaysia. Studies in Conflict and Terrorism, 32(7), 646-663. https://doi.org/10.1080/10576100902945527

Power, T. (2018, October 9). Jokowi's authoritarian turn - New Mandala. Retrieved October 16, 2020, from newmandala.org website: https://www.newmandala.org/jokowisauthoritarian-turn/

Republika. (2017, September 26). Do not spread radicalism in universities: Jokowi | Republika Online. Retrieved October 16, 2020, from republika.co.id website: https://www.republika.co.id/berita/rol-to-campus/universitaspancasila/13/03/14/en/national-politics/17/09/26/owvrux414-do-not-spreadradicalism-in-universities-jokowi

Rodhi, M. M. (2012). Tsaqofah dan Metode Hiz̧but Tabrir dalam Mendirikan Negara Kbilafah. Bogor: Al Azhar Freshzone Publishing.

Sarwanto, A. (2017, May 8). Fahri Hamzah Kritik Rencana Pembubaran HTI. Retrieved October 16, 2020, from cnnindonesia.com website: https://www.cnnindonesia.com/nasional/20170508154220-32-213187/ fahri-hamzahkritik-rencana-pembubaran-hti

Suganda, R., Sutrisno, E., Wardana, I. W., Olowu, T. O., Sundararajan, A., Moghaddami, M., ... Palensky, P. P. (2010). Hizbut Tahrir Indonesia: The Rhetorical Struggle for Survival. In O. Atsushi, O. Masaaki, \& S. Ahmad (Eds.), Islam in Contention: Rethinking Islam and State in Indonesia (pp. 169-213). Retrieved from http://www.eskom.co.za/CustomerCare/TariffsAndCharges/Documents/RSA Distribution Tariff Code Vers 6.pdf\%0Ahttp://www.nersa.org.za/

Valdameri, E. (2017). Indonesia 2017: Towards illiberal democracy? - Asia Maior - An Italian think tank on Asia. Asia Maior, 28. Retrieved from https://www.asiamaior.org/the- 
Copyright (C) 2020, Hasbi Aswar, Danial Bin Mohd Yusof, Rohana Binti Abdul Hamid

This is an open access article under the CC-BY-SA license
ISSN 2088-8090 (Print) ISSN 2597-6648 (Online) Sospol: Jurnal Sosial Politik Vol 6 No 2 (2020), pp 183-200

journal/10-asia-maior-vol-xxviii-2017/indonesia-2017-towards-illiberal-democracy.html Warburton, E., \& Aspinall, E. (2019). Explaining indonesia's democratic regression: Structure, agency and popular opinion. Contemporary Southeast Asia, 41(2), 255-285. https://doi.org/10.1355/cs41-2k

Wiktorowicz, Q. (2004). Islamic Acitism: A Social Movement Theory Approach. Indiana: Indiana University Press. 